\title{
Beyond participation: when citizen engagement leads to undesirable outcomes for nature-based solutions and climate change adaptation
}

\author{
C. Wamsler ${ }^{1}$ (D) J. Alkan-Olsson ${ }^{2} \cdot$ H. Björn ${ }^{3} \cdot$ H. Falck ${ }^{4} \cdot$ H. Hanson ${ }^{2} \cdot$ T. Oskarsson ${ }^{5}$ • \\ E. Simonsson ${ }^{6} \cdot$ F. Zelmerlow ${ }^{7}$
}

Received: 26 March 2019 / Accepted: 10 September 2019 / Published online: 5 November 2019

(C) The Author(s) 2019

\begin{abstract}
Scholars and practitioners are increasingly promoting so-called nature-based approaches for urban climate change adaptation. There is widespread consensus that they both support and require transdisciplinary approaches, notably by involving citizens in the change process and finding innovative ways to unite different actors' efforts and capacities. However, there is little empirical evidence regarding the actual value of citizen involvement to sustainability in this field. Against this background, this paper examines whether (or not) current forms and conditions of citizen involvement help to create a platform to support nature-based solutions and ensure a transformative adaptation process. The results show that under current conditions, citizen engagement often hampers sustainable outcomes. In fact, current structures and mechanisms for mainstreaming nature and climate considerations into sectoral planning are limited and, furthermore, neglect citizen involvement. In addition, there is a blind spot with respect to personal spheres of transformation toward sustainability regarding citizens, civil servants, and decision-makers. Key constraints are power structures and the lack of cognitive/ emotional and relational capacities required for improved democratic governance. If we are to tap into the potential of nature-based solutions to increase climate adaptation governance, we need targeted financial and human resources, and greater capacity to overcome current constraints and support all levels and phases of mainstreaming, notably planning, implementation, monitoring, and learning.
\end{abstract}

Keywords Nature-based solutions $\cdot$ Ecosystem services $\cdot$ Ecosystem-based adaptation . Ecosystem-based planning · Emotions $\cdot$ Climate change adaptation · Disaster risk reduction ·

\section{Highlights}

- Nature-based solutions have the potential to increase citizen involvement in climate adaptation governance.

- Current approaches do not tap into this potential.

- Under current conditions, citizen engagement often hampers sustainability outcomes.

- Citizen involvement requires explicit support and systematic mainstreaming to support sustainability.

- Key constraints are power structures, and cognitive/emotional and relational capacities.

\section{Wamsler}

christine.wamsler@lucsus.lu.se

Extended author information available on the last page of the article 
Citizen participation - Collaborative governance $\cdot$ Sustainability Co-Production - Citizen science Values $\cdot$ Citizen engagement $\cdot$ Public participation

\section{Introduction}

Climate change impacts include an increase in extreme precipitation, inland and coastal flooding, heat stress, drought, and water scarcity. They all pose a serious challenge to sustainable urban development and place cities at increasing risk (IPCC 2014, 2018). In the absence of adequate international responses and given the need for place-based solutions, local authorities have a pivotal role in fostering climate change adaptation (CCA) through its mainstreaming in existing mechanisms and structures (Measham et al. 2011; Roberts et al. 2012; IPCC 2014; Rauken et al. 2014; Wamsler 2014).

In this context, nature-based approaches are being increasingly promoted and their potential to foster sustainability outcomes is receiving greater interest from scholars and governmental bodies alike (Andersson 2006; Faivre et al. 2017; Kabisch et al. 2016; Huq et al. 2013; IPCC 2014; Wilkinson et al. 2013). The concept of nature-based solutions (NBS) is relatively new and can be defined as solutions that use nature and ecosystem services to provide economic, social, and environmental benefits (EC 2015; Maes and Jacobs 2015). Its broad scope spans other concepts, such as urban green infrastructure and ecosystem-based approaches for CCA (Pauleit et al. 2011; Nesshöver et al. 2017). Originally introduced by the World Bank and the International Union for the Conservation of Nature (IUCN), the aim is to raise the profile of biodiversity conservation in tackling climate change (IUCN 2008; MacKinnon et al. 2008). In Europe, it has been adopted into the Horizon 2020 framework program for research and innovation (EC 2015).

There is widespread consensus that nature-based adaptation planning both supports and requires transdisciplinary approaches, including involving citizens in change and finding innovative ways to unite different actors' efforts and capacities (Eggermont et al. 2015; Kabisch et al. 2016; Nesshöver et al. 2017; Wamsler 2017). The motivations are manifold. First, climatic conditions are changing rapidly, as are their impacts on urban areas, reducing the capacity of local authorities and associated governance systems to deal with them (Romero Lankao 2008; Davoudi et al. 2010; Wamsler and Brink 2014a, 2014b). Second, climate change interacts with other socioeconomic, physical, and ecological drivers of urban risk at different scales in the context of both private and municipal land use (IPCC 2014, 2018). This challenges the division of responsibility between local authorities and citizens when adapting to climate events (Adger et al. 2013; O’Brien et al. 2009; Sarzynski 2015; Mees et al. 2019; Wamsler 2016, 2018). This situation has given rise to questions about alternative approaches to city-citizen co-production and led to the emergence of commoning climate adaptation (Wamsler and Raggers 2018). Finally, the need for transdisciplinarity and citizen involvement is widely claimed to increase relevance; fairness; acceptance; and, ultimately, sustainability (Adger et al. 2005; Burton and Mustelin 2013; Lemos and Agrawal 2006; Renn and Schweizer 2009; Mees et al. 2015; Nesshöver et al. 2017).

Despite the widespread understanding that citizen involvement is per se necessary and positive, and that it leads to more sustainable outcomes, there is almost no empirical evidence to suggest that it supports NBS to ensure continuous and transformative 
adaptation in cities (cf. Glaas et al. 2015; Hegger et al. 2017; Mees et al. 2016, 2017, 2019; Waylen et al. 2015). ${ }^{1}$

Against this background, this paper examines whether current forms and related conditions of citizen involvement help (or not) to create a platform to support nature-based approaches for sustainability in municipal adaptation planning. More specifically, we identify patterns in relation to (i) current citizen involvement and its links to sustainability outcomes and (ii) associated conditions in the form of drivers and barriers. Finally, we discuss the relevance of these results in relation to the current literature and practices, and conclude with some policy recommendations and further research needs.

\section{Methodology}

This paper is based on a participatory analysis (Burns 2007; Glassman and Erdem 2014; Greenwood and Levin 2006) of Swedish municipalities to explore whether current forms of citizen involvement help or hinder sustainability outcomes by supporting nature-based approaches in municipal adaptation planning. To do so, in 2018, we established an interdisciplinary learning lab in the southern region of Scania in Sweden.

Sweden is an interesting subject for case studies in this field. It is a declared pioneer in climate change and environmental governance (DC 2014; Hertin and Berkhout 2001; Jordan and Lenschow 2000) and tops the Global Green Economy Index (DC 2014). CCA and the consideration of ecosystem services are stated government goals (SOU 2007; SOU 2013; Ministry of the Environment 2013). The Scania region has made particular progress (Länsstyrelsen i Skåne län 2014). Consistent with the participatory approach (Burns 2007; Greenwood and Levin 2007), municipalities were selected based on four criteria: (i) their risk exposure (Länsstyrelserna 2012; SMHI 2011), (ii) the role and proactive engagement of their staff in promoting NBS and CCA, and (iii) their interest in participating in the learning lab and related activities. A further criterion was the representation of municipalities of different sizes.

Accordingly, the lab brought together representatives from five municipalities (Malmö, Lomma, Eslöv, Höganäs, and Kristianstad) and scholars from different backgrounds. Six scholars from three academic institutions and eight municipal representatives participated. The lab was based on local needs and a desire for increased knowledge exchange, which were identified during a joint workshop in 2017. ${ }^{2}$ Participants at the latter workshop developed the overall aims of the project, namely to systematically analyze, compare, and learn from the integration of nature-based approaches for climate adaptation into their daily planning practice and, in this context, analyze associated governance mechanisms and stakeholder involvement. Each municipality selected cases, which were subject to a step-by-step analysis, from the initial project idea, to comprehensive and/or detailed planning, procurement, implementation, maintenance, and follow-up (monitoring and evaluation). The cases were representative of how municipalities addressed NBS, CCA, and

\footnotetext{
${ }^{1}$ Exceptions come from related fields, such as landscape planning (e.g., Clausen 2017; Tippett et al. 2007; Beierle and Konisky 2000) environmental impact assessment (O'Faircheallaigh 2010; Glicken 2000), climate change mitigation (Bulkeley and Mol 2003), resource management (Irvin and Stansbury 2004; Waylen et al. 2015), or beehiving (Purcell and Brown 2005). Others relate to participatory governance of urban green spaces in general (e.g., van der Jagt et al. 2016). See also footnote 3).

${ }^{2}$ The city-to-city learning lab was an outcome of a joint workshop organized by Mistra Urban Futures Skåne and the Skåne Association of Local Authorities at Malmö Högskola University on April 27, 2017. Participants were selected based on their expertise and knowledge of ecosystem- and nature-based approaches to support sustainable municipal development.
} 
related citizen involvement in development planning processes; four focused on the creation of new residential areas and three on targeted interventions within existing areas, notably green privatepublic nodes, a school complex and a green embankment (Annex 1). ${ }^{3}$ The municipal staff who participated in the lab were directly involved in these cases, being the project coordinators, planners, and environmental strategists with good overview of all planning steps and phases.

Data were collected in 2018-2019 during a series of workshops and field visits, group discussions, participatory observations, interviews, ongoing dialogue with key informants, and from a literature review. The latter included project-related articles, descriptions, policies, citizen surveys, and protocols from relevant citizen dialogues or planning walks to capture different stakeholders' perspectives. Seven case-specific workshops, five field visits to the case study areas, and 12 interviews were conducted and transcribed to assess municipal staff's perceptions. The workshops and interviews followed the same format, which was based on the jointly developed analytical framework (Annex 2) that built upon mainstreaming and citizen involvement typologies (Brink 2018; O'Brien and Sygna 2013; Runhaar et al. 2018; Wamsler and Pauleit 2016; Wamsler and Brink 2018). ${ }^{4}$ Accordingly, all cases were systematically analyzed by going through the different planning phases to discuss the consideration of NBS, CCA, and related citizen involvement (Annex 2). Additional workshops on related topics (urban greening and citizen participation) enabled further dialogue throughout the process. Data were analyzed with a combination of literal reading, grounded theory (Glaser and Strauss 1967) and systems theory (Bateson 1979), ${ }^{5}$ and systematized based on the jointly developed analysis framework. The identification and analysis of relevant data was organized into five phases: (1) coding scheme development in accordance with the analytical framework, (2) identification of potentially relevant texts, (3) application of the coding scheme, and (4) identification of patterns. The preliminary results and ensuing conclusions were then discussed and revised by municipal staff and lab members before they were revised and finalized. ${ }^{6}$

\section{Results}

The following subsections present our results as a set of patterns in relation to (i) current citizen involvement and its links to sustainability outcomes (Section 3.1) and (ii) associated conditions in the form of drivers and barriers (Section 3.2).

\footnotetext{
${ }^{3}$ Unlike the existing literature on citizen involvement related to NBS and/or CCA, this study did not start with a focus on (selecting) relevant cases of (successful) citizen involvement (cf. van Ham and Klimmek 2017). Instead, it focused on projects relevant to NBS in urban CCA and how they have been influenced by citizen involvement. Thus, the paper presented here does not focus on citizen-driven initiatives and nor on initiatives by local authorities that aimed to promote citizen-led initiatives (cf. Buijs et al. 2017). This different starting point allowed for new perspectives and a more critical analysis of current mechanisms and structures.

${ }^{4}$ Typologies of citizen involvement in NBS and CCA relate to citizens' role as (i) being at risk, (ii) being an agent for NBS/CCA, and (iii) being affected by NBS/CCA policies (Brink 2018). Related spheres of activity include (i) the (positive or negative) influence on related municipal work; (ii) reliance on municipal work; and (iii) the reduction of individual or others' risk (Wamsler and Brink 2018). Mainstreaming relates to the systematic integration of NBS/CCA considerations and related citizen involvement at local, institutional, and interinstitutional levels. It includes changes in policy, regulations, planning tools, working structures, mandates, finances, and human resources (Runhaar et al. 2018; Wamsler 2014; Wamsler and Pauleit 2016) that span personal, practical, and political spheres of transformation (O'Brien and Sygna 2013). See Annex 2.

${ }^{5}$ The combination of grounded theory and systems theory involves that during axial coding, the commonly used linear paradigm model was expanded by a broader (non-linear) systems analysis approach.

${ }^{6}$ Due to this process of knowledge co-production, municipal stakeholders are included as coauthors of this study. However, text citations are anonymized in order to provide insights without compromising privacy and political issues.
} 


\subsection{Citizen involvement versus sustainability outcomes}

The cases exemplified different types of city-citizen interactions related to formal participation processes; methods aimed at information gathering (e.g., surveys, informal interviews, digital dialogues), awareness raising (planning walks and games); co-production (e.g., joint workshops, the BID process, guidelines); and citizen contestation (e.g., formal appeals or informal protests and disputes) (Table 1).

Overall several cross-cutting patterns were identified regarding the links between current citizen engagement and sustainability outcomes, which are explained in the following text:

- Under current conditions, citizen engagement often hinders sustainability outcomes.

- It takes the form of (i) explicit contestation of municipalities' NBS/CCA considerations; (ii) inaction (no contestation) regarding approaches that ignore NBS/CCA considerations; (iii) lack of civic engagement (and sense of responsibility) for NBS/CCA considerations; and (iv) active ignorance of legal provisions that ensure NBS/CCA considerations.

- In the few cases where citizen engagement (contestation) led to positive outcomes for NBS/CCA considerations, they were mostly unintended.

- Consequently, municipalities' work on citizen involvement is driven by strategic reasons to increase validity (for democratic planning) and deal with current, or prevent future, conflicts that could hinder efficient implementation and sustainability outcomes. Accordingly, a significant amount of municipalities' human and financial resources go into "working against" negative citizen engagement.

- Under current conditions, increasing citizen involvement is rather counterproductive.

Table 1 Identified types of city-citizen interactions

\begin{tabular}{|c|c|c|}
\hline \multirow[t]{2}{*}{ Municipality } & \multicolumn{2}{|l|}{ City-citizen interactions } \\
\hline & Municipality-driven & Citizen-based \\
\hline Eslöv & $\begin{array}{l}\text { - Formal participation in the planning } \\
\text { process } \\
\text { - Citizen survey to obtain information on } \\
\text { cultural ecosystem services. }\end{array}$ & $\begin{array}{l}\text { - Civil protests about planning proposals (a } \\
\text { mosque) } \\
\text { - Neighbor contestation (appeal against the } \\
\text { detailed plan) }\end{array}$ \\
\hline Lomma & $\begin{array}{l}\text { - Formal participation in the planning } \\
\text { process } \\
\text { - Joint workshops with neighbors and } \\
\text { teachers, respectively }\end{array}$ & - Disputes between neighbors \\
\hline Malmö/Sofielund & $\begin{array}{l}\text { - Inclusive stakeholder involvement process } \\
\text { (the so-called BID process) }^{\mathrm{a}} \\
\text { - Guidelines for citizens's self-governed } \\
\text { NBS/CCA }\end{array}$ & $\begin{array}{l}\text { - Stakeholder fatigue (due to lack of actual } \\
\text { outcomes of own engagement) }\end{array}$ \\
\hline Kristianstad/Åhus & $\begin{array}{l}\text { - Formal participation process } \\
\text { - Dialogue with neighbors/neighboring en- } \\
\text { terprises }\end{array}$ & $\begin{array}{l}\text { - Individual disputes between } \\
\text { neighbors/neighboring enterprises }\end{array}$ \\
\hline Höganäs & $\begin{array}{l}\text { - Formal participation in the planning } \\
\text { process } \\
\text { - Citizen planning walks } \\
\text { - Citizen planning games } \\
\text { - Digital dialogue (whole city) }\end{array}$ & $\begin{array}{l}\text { - Formal appeals and protest from neighbors } \\
\text { - Individual disputes }\end{array}$ \\
\hline
\end{tabular}

a BID process: In 2014, local property owners and companies, with support from the city, took action and formed a non-profit organization, involving substantial economic responsibility and joining resources. 
The results show that under current conditions, citizen involvement often hinders sustainability outcomes. In fact, in all municipalities, it negatively affected the consideration of NBS and CCA, both explicitly and implicitly.

There were for instance ample examples of citizens' contesting NBS/CCA considerations, including small-scale (e.g., individual statements or disputes during hearings) and large-scale actions (e.g., organized appeals against municipal plans). Contestation was often based on individual personal interests and a lack of environmental awareness, and had a considerable impact on the planning process due to lengthy, resource-consuming delays in, and the reduction of, NBS/CCA considerations.

Personal interests typically related to mobility issues, in the form of a car-friendly environment that provides sufficient, free parking space and good access through hard infrastructure. Independent of the type of involvement, experiences in different areas are very similar. As one municipal representative describes:

(...) ordinary public hearing(s), with ordinary comments: People thought that the plan was not car friendly enough. People wanted to have roundabouts just next to the area. What comes from citizens is rather counterproductive for nature or adaptation considerations. People were afraid that the infrastructure would not be enough, that it would be difficult for them to drive their car. We were focusing on greening, walking paths and biking paths, ... no one was really interested in this. You never hear people say anything good in these meetings, because it's only those with negative perspectives who come. Now we have to [put more resources into] doing more calculations regarding the traffic...

Another says,

Everybody wants to have their own roads and roundabouts (...). We also had special dialogues with them, which is not part of the formal participation process. As a result, the distance between the new area and businesses was increased [to guarantee better access for all].

In most cases, citizen engagement "was not a question of nature or climate, more a question of parking space." In one city, the issue of parking space even led to neighbors overruling the municipality's plans, "They wanted to make sure that they can park their cars here."

Other personal arguments that conflict with NBS/CCA considerations include apparent contamination (noise and bird droppings due to greening), the creation of shade (due to trees or buildings), too close-by multi-story housing (that would allow room for greening or protecting arable land), or constructions that might restrict a sea view (e.g., green embankments). In fact, in one area:

They gave the municipality a list of 180 protesters because they did not like the project. It was not about green or adaptation considerations. It was only about: 'We do not like multi-story houses.'

People do not care as long as they have their private villa close to the sea, they do not care about climate change because they cannot see it now.

Neighbors are [also] worried about shade....it is not a climate perspective. It is an economic perspective. If you have shade $24 / 7$ in your backyard, you'll get less money when you want to sell the house.

In another area: 
(...) when the municipality suggested that they should protect the trees, several citizens were against this. We were told that there are too many bird droppings in the area and there is so much noise from the birds, and that's why we can't have trees in the city...,

In the case of the construction of a sea wall:

External stakeholder involvement was huge. It is a very interesting example. There is a whole row of exclusive villas along that wall, and half of them wanted the wall because they got flooded, and half didn't want to have the wall because their (sea) view would be destroyed. So they wouldn't have a sea view anymore. And it was basically uproar. People came to our meetings. We had many meetings with the people living there. They were so upset, basically throwing things at us. There were a lot of discussions and meetings.

Contestation can be powerful, as political issues such as votes and tax income are significant drivers of municipal decision-making. "They created an appeal that made the politicians afraid so that they withdrew the proposal first, because they were afraid to lose votes." Municipalities also want to "please" their inhabitants. Their aim is, for example, that "young people will not move to [the next bigger city] Helsingborg but stay." In the few cases, where contestation led to positive NBS/CCA outcomes, it was unintended. In one case, environmental reasons triggered contestation, but only because it hid a strategic push for other, personal interests:

Instead of saying we don't like taller houses, they used their brains to demand more consideration be given to environmental perspectives. But their real objective was to stop or slow down the project, in other words, to gain time to increase citizen resistance.

Earlier in the process,

In the initial planning process -180 people sent letters to the municipality and they had to withdraw the project - because they don't like taller buildings. But at the same time the planner can't use farm land and then do not use it efficiently (for one story houses only), which meant that they needed other arguments against the project.

In the end,

The municipality had to create an additional environmental impact assessment, 47 pages long, describing every detail of the area (including the risk of flooding). It is interesting to see how we got here, it wasn't because of interest in the environment, it was because they tried to find arguments against the project - against multi-story buildings. Now the detailed planning has been done. Now it is with the 'land and environmental court' - this is the normal process if someone opposes certain plans. They were fighting us to the end and therefore it had to go there. The detailed plans show how environmental issues have been taken into account, they refer to the impact assessment. So, in this case, consideration of the environment was spurred by the people, but not because of their environmental concerns

A second example shows how contestation led to unintended, positive outcomes for NBS/ CCA. It took place during the initial planning phase, when:

The architects wrote in a proposal that a mosque could be built in the planning area. This caused a minor riot. They said that because they wanted to be open to any suggestions, the square could be used for many reasons, and this was just one potential idea. They 
had a lot of suggestions, but this is what the newspaper highlighted... (...). It caused an organizational change within the municipality: architects were moved closer to the politicians (so that they couldn't make similar statements again). They were moved higher up in the hierarchy. This was positive in relation to the consideration of NBS and CCA because they were closer to civil servants who decided what land to buy and sell and under what conditions (...) Now, thankfully, to the mosque. They put us together with the property management department. The engineers there don't know anything about NBS or CCA, so I can tell them to add these issues, for instance, to the tender requirements. So, now we can create a red line [for incorporating NBS/ CCA considerations] running from the comprehensive plan to the detailed plan to the call for tenders.

The second type of citizen engagement that often hinders sustainability outcomes takes the form of inaction regarding municipalities' approaches that neglect NBS/CCA consideration in the planning process. It is often driven by political issues or a lack of awareness regarding how to approach the municipality. One example involved the destruction of the so-called people's park.

During the implementation process citizens didn't complain. There was surprisingly little reaction. I think that it was also a political statement, because now the conservative party is in power, and the people's park is a left-leaning cultural park, with a lot of places named after former politicians (...) and there are symbolic monuments (...). The new redevelopment project meant removing the last resource or evidence that it was a leftwing city, a workers' town, a big mining city with a lot of workers. Now it's an exclusive area for rich people working in Helsingborg, commuting and travelling to other places.

Another obstacle to sustainability outcomes is the lack of civic engagement in public life and the promotion of high-quality communities, including NBS/CCA considerations. This lack of interest in (or time for) participation is linked to unclear responsibilities and a reliance on municipalities to solve NBS and CCA issues (e.g., regarding NBS for water and floor risk management).

The problem is that property owners blame the city. They say that the water systems we have aren't good enough, and the municipality blames property owners, saying that they didn't think hard enough before repairing or rebuilding their house and gardens. So, this is a problem.

People put all the blame on politicians. This is the biggest problem really. But it's not really fair, because a lot of people are involved.

In addition, people think that involvement will not lead to actual changes, which is linked to the way municipalities currently involve citizens (see below). Consequently, all municipal representatives stated that few people showed up to participatory meetings or public consultations, while those that opposed plans were overrepresented, creating frustration among municipal staff:

I can't understand why they don't take it seriously. How do we reach out to them? How do we get them to understand? I can't understand why. What is happening in this world, when nobody wants to listen?

A further challenge is citizens' ignorance of legal provisions regarding NBS/CCA considerations. For instance, the construction of the "green" sea wall was problematic because: 
Several people had built on municipal land, they didn't own the land, they just took it and built on it, for example for garden sheds, fences, even quite expensive winter gardens with a view of the sea. All of that had to be taken down. First, they opposed the wall, and then we said 'you've appropriated our land and you have to move back'. In some cases, they'd built over 50 meters into municipal land. They'd also sold houses saying that the garden goes all the way to.... So some people didn't know... That was very dramatic for some people.

The few examples of citizen involvement with positive impacts on NBS/CCA relate to information gathering or provision that was not linked to a specific municipal intervention and, thus, did not create a conflict of interest with the people involved. Examples are the school complex, the development of recommendations for personal climate actions, and the general (i.e., not project-specific) digital dialogues and citizen surveys in Höganäs and Eslöv (cf. Table 1).

We sent a survey to citizens... They had to answer questions and place dots on a map regarding their use of, and needs for, green space. The survey showed that there was a lack of greenery. We already knew that. It wasn't rocket science. But it also showed an actual demand for greenery. It showed that the square (in the detailed planning project) lacked greenery, and here we had an opportunity to add greenery, to add NBS. So, that was my idea. Densify and at the same time get greener.

Despite this apparent win-win situation, the proposed plan was later overruled by neighbors (see above).

Due to the described situation, municipalities' citizen involvement activities are mainly driven by legal and strategic concerns. The latter is aimed at (i) dealing with existing, or preventing future conflicts that hinder efficient implementation and sustainability outcomes ${ }^{7}$ and (ii) increasing validity for democratic planning purposes. Much time and resources thus go into arguing with citizens to ensure sustainability outcomes: "It consumes time... to deal with the neighbors... but it's part of the process."

After the public hearing you rework the plan, then you go to the next hearing. That's the democratic way the planning process is done. But perhaps neighbors don't always think about everybody's best interest, you have to consider the 'greater good'.

In the case of contestation, "the minimum time to solve appeals is six months and often it takes longer." Nevertheless, citizen involvement is often claimed to be per se positive and is assumed to lead to more democratic (and presumably sustainable) outcomes, which, in turn, influences current approaches.

Given current structural conditions, increasing citizen engagement can also be counterproductive. Contestation and power issues dominate and block efforts (cf. Section 3.2) leading, for instance, to increasing stakeholder fatigue.

In the BID process, there are a lot of stakeholders who are very interested in creating more green areas, keeping existing green areas, and they're also very interested in

\footnotetext{
${ }^{7}$ Strategic reasons for citizen engagement can, thus, go beyond inadequate citizen engagement. They might also lead municipal staff to resort to even more strategic behavior, creating a vicious cycle, caused by current conditions (cf. Section 3.2).
} 
finding solutions for CCA, like ponds, etc., but something is stopping the process... they're so tired of sitting in workshops. Nothing concrete is happening.

\subsection{Drivers and barriers}

The analysis of drivers and barriers shows that it is structural conditions (structures, mechanisms and capacities) that negatively influence current forms of citizen involvement.

The identified drivers and barriers regarding citizen support for sustainability outcomes are as follows:

- A lack of municipal capacity to encourage constructive involvement that can support both democratic approaches and sustainability outcomes.

- This relates to power structures and a lack of an adequate support structure for systematic mainstreaming of NBS/CCA and related citizen involvement at institutional level, aspects that are linked to political and practical spheres of transformation.

- Drivers and barriers at personal level relate to people's environmental awareness and beliefs, their "irrational" behavior, how they see their relationship to others and the environment, social power structures (linked to education, income, long-term residents/ newcomers, political orientations, and groupings), and individual perceptions of influence and responsibilities.

Current conditions relate to a lack of adequate mechanisms and structures for more positive citizen involvement and associated mainstreaming of NBS and CCA into municipal work (Table 2). This includes a lack of political support, policies, regulations, working conditions and structures, planning tools, and financial and human resources. Existing regulations do not, for instance, require citizen involvement beyond formal consultation processes. ${ }^{8}$ In addition, local planning regulations are restricted regarding the use of private land for public purposes, which hampers the development of more innovative forms of cooperation.

There is a conflict ... it's very interesting to look at how to solve it... I've presented these cases to lawyers, but they always say that it's not possible because it involves private landlords, private land, and this is why we cannot work together.

In addition, there is a lack of mechanisms and structures for monitoring and learning. "Nobody takes care of what we know and how we can use existing knowledge in other areas." This would require targeted financial and human resources for citizen involvement and NBS/CCA mainstreaming, but is not given priority. "Economic perspectives drive municipalities' work and priorities." In addition, current approaches, working conditions, and structures are characterized by high staff turnover and long planning horizons, which can span up to 10-20 years. "The longer it takes, the more difficult it becomes to follow things through." Furthermore, positive citizen involvement can be hampered by the lack of political influence (and associated resources) of the departments or geographical areas involved.

The low level of mainstreaming leads municipalities to focus on internal issues, rather than looking into external stakeholder involvement.

\footnotetext{
${ }^{8}$ Public consultation has deep roots in Sweden (OECD 2010; Bjärstig et al. 2018). Its form, however, is not regulated and is very much a municipal decision. Legislation requires however that planning proposals have to be made fully available to the public for at least two months before they are adopted (SFS 2010:900; Bjärstig 2018).
} 
Table 2 Barriers and drivers

Barriers and drivers

\begin{tabular}{ll}
\hline $\begin{array}{l}\text { Municipalities - Political } \\
\text { and practical spheres }\end{array}$ & - Lack of supporting policies, regulations, and planning tools \\
& - Lack of financial and human resources \\
& - Working conditions and structures \\
& - Traditional ways of planning (little stakeholder involvement, \\
& technical focus, etc.) \\
& - Cognitive/emotional and relational capacities needed to address \\
& personal spheres of transformation \\
& - Personal/conflicting interests \\
& - Immunity to change/“people do not like change.” \\
& - Lack of environmental awareness and belief in climate change \\
Citizens - Personal spheres & - Education, income, age, and political orientation \\
& - Pre-existing conflicts, experience and/or place attachment \\
& - Social power structures and networks \\
& - Perceptions of individual influence and responsibility \\
&
\end{tabular}

We decided to start at the institutional level first, with municipal land, before making private people working with NBS and CCA.

When I started to make detailed plans in 2014, the only thing I had to lean on regarding NBS and CCA was [outdated], from more than 10 years ago ... the mechanisms and structures that are in place do not ensure that input and tools are in place.

Consequently, citizen involvement is low on the list of priorities and there is no systematic way to collect their perspectives, needs, and capacities. Similarly, innovative forms of cooperation, including increased interaction of different citizen groups and at different stages in the planning process, are lacking (e.g., citizen representatives in the tender process). The few instances are ad hoc and based on engaged individual members of staff (champions) learningby-doing, which is itself limited to pre-planning phases.

We have the advantage of having recent graduates, with fresh knowledge, who can add something to the project. Each of my new colleagues has invented a new method for citizen dialogue. That's why we're also starting to look into virtual reality and other technological stuff, which our older colleagues may not have done.

However, under the current structural conditions, municipalities lack the capacity to systematically encourage positive citizen involvement in support of democratic approaches and sustainability outcomes. Increasing such capacities requires an adequate support structure and mechanisms at institutional and inter-institutional levels to also address the drivers and barriers at an individual level and to tap into personal spheres of transformation (cf. Table 2).

Stakeholder involvement is always also a matter of psychology and making people understand why this [i.e. NBS/ CCA] is important even for them. It is not a legal thing; it's something else. You need to make that work, and that's really another subject. You need to reach people.

This statement is representative of the many individual-level drivers and barriers that were identified. These include strong emotions, place attachment, (non)environmental awareness and beliefs, "irrational" behavior, how they see their relationship to others and the environment, social power structures (linked to education, income, long-term residents/newcomers, political orientations, and groupings), and individual perceptions of influence and 
responsibilities. The relevance of these aspects becomes especially obvious when dealing with different geographical areas and groups. For instance, in certain areas:

In the center people aren't very highly educated. They don't care much about changes in the city, such as the park redevelopment. In the other area, they have a local organization that's very strong, and if something new happens, they oppose it (...). They oppose everything: They're rich, often more educated people, and if you suggest putting rental housing nearby, they don't want it.

This statement, similar to other examples, shows the strong emotions involved in all cases of contestation, and how they are embedded in people's values, worldviews, and belief systems.

There's been a big fight - people writing about how they hate the project, that politicians are corrupt, etc. They were so upset, basically throwing things at us. These people don't care as long as they have their private villa close to the sea, they don't care about climate change because they can't see it yet.

It's because of local conservatives, they don't like change, so if you want to build something you need have the town's influential people on your side.

There's not much political interest in nature, but even more so, citizens aren't interested.

In some cases, different levels of place attachment and experiences were an important factor:

They have different houses. The worst-affected houses were newly built from the $80 \mathrm{~s}$, and then there's a long row of quite old houses (...). Younger people were in the more northern areas and older people in the more southern. The older ones in their old houses didn't understand why the young people had to have televisions and things like that in their basements. There was a big difference in how they used their house and what they expected to do in it. Because they had lived there for 50 years and said: 'If there's a flood, there'll be water in your house, what's the problem?' (...) The older ones have a cellar, but they don't use it for living space, which makes a big difference to the amount of damage.

They didn't support us much, they were fighting the other group, because they'd been flooded, they had 1.2 meters of water on their ground floor, flooded, and it was going to take them around three years to rebuild their homes in order to be able to live there again. So, this [young] group [of residents] was asking the opponents if they thought that that was ok and that this wasn't very human.

\section{Discussion and conclusions}

Five important issues emerge from our results. First, the widespread understanding that citizen involvement in NBS and CCA per se leads to more positive, sustainable outcomes does not hold true. Although several theoretical papers discuss related issues (e.g., Bulkeley and Mol 2003; Cooke and Kothari 2001; Purcell 2006), few studies have challenged these assumptions in the context of NBS for urban CCA. ${ }^{9}$ This paper fills this gap. While not specifically analyzing related outcomes, drivers, and barriers, several studies from other countries have highlighted the limitations or disadvantages of citizen involvement (e.g., Clausen 2017; Mees et al. 2019; Mattijssen et al. 2018; Irvin and Stansbury 2004; Waylen et al. 2015), suggesting that our results

\footnotetext{
${ }^{9}$ See footnote 1 .
} 
are valid beyond the area examined in this study. Learning from positive examples of citizen involvement and self-governance is important (e.g., van der Jagt et al. 2016; van Ham and Klimmek 2017), ${ }^{10}$ but not sufficient. Critical analyses of other, unsuccessful cases regarding NBS for CCA are crucial if we are to avoid maladaptation and improve current approaches to democratic governance.

Second, our finding that current citizen involvement in NBS and CCA often hampers sustainable outcomes does not question its relevance but the current structural conditions in place, i.e., the fact that current processes for mainstreaming nature and climate considerations into sectoral planning remain limited, and citizen involvement continues to be regarded as a secondary consideration in this context (cf. Waylen 2015). While municipalities are gradually shifting toward more networking, cooperating, facilitating, and enabling roles, and the idea of the city as a commons is gaining momentum (LabGov 2019), there is a clear lack of organizational flexibility and support to facilitate citizen involvement (cf. Mees et al. 2019) that goes beyond stakeholder interactions as a "technocratic compromise" (Checker 2011). Consequently, involvement tends to be punctual, isolated, and often counterproductive, even when authorities increase their efforts in some areas. This outcome supports studies that have demonstrated the lack of CCA mainstreaming and associated citizen involvement worldwide (Runhaar et al. 2018). It links to the vast literature that has demonstrated the need to combine multiple types of mainstreaming measures and strategies at the local, institutional, and interinstitutional level in order to achieve sustainable outcomes (Runhaar et al. 2018, Wamsler 2014, Wamsler and Pauleit 2016; cf. Annex 2). However, in practice, a comprehensive approach is currently lacking. At the same time, our results indicate weaknesses in the mainstreaming literature, which has so far focused on political and practical spheres of transformation (cf. O’Brien 2018; Wamsler and Raggers 2018), which leads us to the third implication of this study.

Third, our results reflect the current focus on political and practical spheres of transformation worldwide, and the clear blind spot with respect to personal spheres regarding citizens, civil servants, and decision-makers. Systemic transformation, which addresses all three spheres of transformation, is however necessary to address sustainability challenges such as climate change (O’Brien and Sygna 2014). Systems possess different "leverage points," where interventions can be targeted to bring about sustainable transformation. Shallow leverage points consist of parameters, such as taxes or incentives, and feedback (i.e., interactions between system elements) (Abson et al. 2017; Meadows 1999), and they have tended to be the focus of sustainability policies to date. In contrast, deep leverage points are more difficult to influence, but lead to more substantial change. They include the design and "intent" of the system, i.e., the underlying values, beliefs, and worldviews of actors, aspects that also emerged from our results.

The lack of consideration given to such personal spheres of transformation in NBS and CCA illustrates a general concern in sustainability science and practice (Parodi and Tami 2018; Wamsler 2018a). It is often the case that NBS, CCA, and cooperation drivers cannot be considered "rational" as defined by rational choice theory (Shogren and Taylor 2008). This has an impact on risk perceptions, general environmental behavior, and

\footnotetext{
${ }^{10}$ Related examples were also systematised in the context of the research project(s) that led to this study (see under https://lucsus.prodwebb.lu.se/research/urban-governance/urban-transformation and https://www.lucsus.lu. se/klimatsamverkan).
} 
individual motivation to take, or support, municipal actions in these fields (Nightingale 2015; Wamsler and Raggers 2018). Our results thus support other studies that highlight the importance of considering, and providing space for, a comprehensive understanding of risk and its systemic root causes - and for alternative ("irrational") behaviors that address them (Wamsler and Raggers 2018). The latter takes account of subjectivities (cf. Table 2), which are as important as power structures when managing nature and climate adaptation (Wamsler and Raggers 2018). Subjectivities are central to the operation of city administrations, as they are an integral part of how people understand their relationship to others. This means identifying capacities, practices, and interactions, and focusing on how they can both promote and frustrate attempts to collaborate. Individuals can for instance feel defensive when interacting with municipal stakeholders (cf. Few et al. 2007; Nightingale 2015; Wamsler and Raggers 2018). For example, they may be blamed for increasing climate risk, forced to provide personal information, or asked to interact with decision-makers, opening up opportunities for power asymmetries to be addressed or reproduced. This can either lead to resistance and a lack of cooperation, or citizens who are readier to work together (cf. Hardin 2013; Lewis and Weigert 1985). Meeting spaces can shape whether policy approaches are accepted, and whether they address the most vulnerable/marginalized members of society (Nightingale 2015, 2017; Wamsler and Raggers 2018).

Fourth, addressing personal spheres of transformation requires civil servants and decisionmakers to develop new capacities. The increasing emphasis on participatory forms of governance (partnerships and the co-production of policies) that are designed to address complex, "wicked" problems leads to more complex and challenging working practices (cf. Folke et al. 2005; Hassenforder et al. 2015; Rowe and Frewer 2004; World Bank 2015). Consequently, there is a growing recognition of the need to address the cognitive/emotional and relational qualities of decision-makers and civil servants to help them deal with the increasing complexity and diversity of modern governance (Bristow 2019; Brink and Wamsler 2019; Wamsler and Raggers 2018), which has also been highlighted in a recent European Commission report (Mair et al. 2019). The idea of rational, objective, unbiased, and emotionally balanced civil servants has long held sway in academic writings on the state and within governmental organizations (e.g., Weber 1991; Jones 2008). And, yet, there is a growing understanding that they are neither rational nor objective (Mair et al. 2019). Cognitive, emotional, and relational qualities influence for instance how they analyze evidence, communicate risk, negotiate and relate with each other, develop productive and positive relationships with civil society, address conflict, take decisions, and develop policy (Blennow et al. 2014; Lilley et al. 2014; Bristow 2019; Sutherland 2018; Wamsler 2018b). At the same time, emotions such as insecurity and threat can lead to hierarchical and siloed working practices (Jones 2008), with implications for policy innovation and institutional design (especially affecting cross-cutting topics such as NBS and CCA). This has serious implications for democratic governance. Our results show that further research is needed to look into ways to better address these issues.

Finally, our results indicate that under certain conditions citizens are more likely to engage in issues related to nature than climate adaptation. This observation supports arguments that NBS has the potential to encourage engagement in climate adaptation (Wamsler and Raggers 2018; Brink and Wamsler 2018). However, this potential has not, so far, been tapped. This brings us full circle, as it relates to the lack of consideration of personal spheres of transformation regarding citizens, civil servants, and decision-makers, and the lack of systematic support for developing more wide-reaching and innovative ways to collaborate. We conclude that if we are 
to tap into the potential of NBS to increase inclusive climate adaptation governance, we need targeted financial and human resources to support stakeholder involvement and personal capacity development and at the same time establish adequate mechanisms and structures that can overcome current constraints and support all levels and phases of mainstreaming to create new narratives, from the early planning stages, to implementation, monitoring, and learning.

Acknowledgements We thank all project participants for their constructive feedback and input. Special thanks to Sanna Stålhammar and Björn Wickenberg for transcribing the Learning Lab workshops and site visits.

Funding information Open access funding provided by Lund University. This research was conducted in the context of two projects: The "Sustainable Urban Transformation for Climate Change Adaptation" project (grant number 2011-901) financed by the Swedish Research Council FORMAS, and the project funded by Mistra Urban Futures to create a "City-to-City Learning Lab on Natura-based Planning and Adaptation." The research has also benefited from two of the authors' participation in the EU-financed Nature-Based Urban Innovation (NATURVATION) project.

\section{Compliance with ethical standards}

Conflict of interest The authors declare that they have no conflict of interest.

\section{Annex 1}

Malmö Municipality (ca. 340,000 inhabitants)

The case concerns the central urban district of Sofielund, one of the most flood-prone areas in the city, and its development/rehabilitation through the so-called BID process, including citizen guidance and the co-development of green areas.

Höganäs Municipality (ca. 27,000)

The first case is an urban regeneration project (detailed plan) for the Folkets ("peoples") Park and a football field, which will generate around 200 new housing units (mainly apartments). The second case concerns Potatisåkern (the potato field) in Viken, which will generate about 100 new housing units (mainly apartments and terraced houses) on former farm land next to a residential area and close to the sea (detailed plan).

Kristianstad Municipality (ca. 85,000)

The case concerns an urban development project (detailed plan) on agricultural land in Åhus. The sandy soil is particularly valuable for biodiversity. The project will generate around 300 new housing units (detached houses and apartments).

Eslöv Municipality (ca. 34,000)

The case describes an urban regeneration project (detailed plan) for a central square. The project will generate around 90 new housing units.

Lomma Municipality (ca. 25,000)

The case includes the development of a school and a flood protection barrier (detailed plans) next to the coast. 


\section{Annex 2}

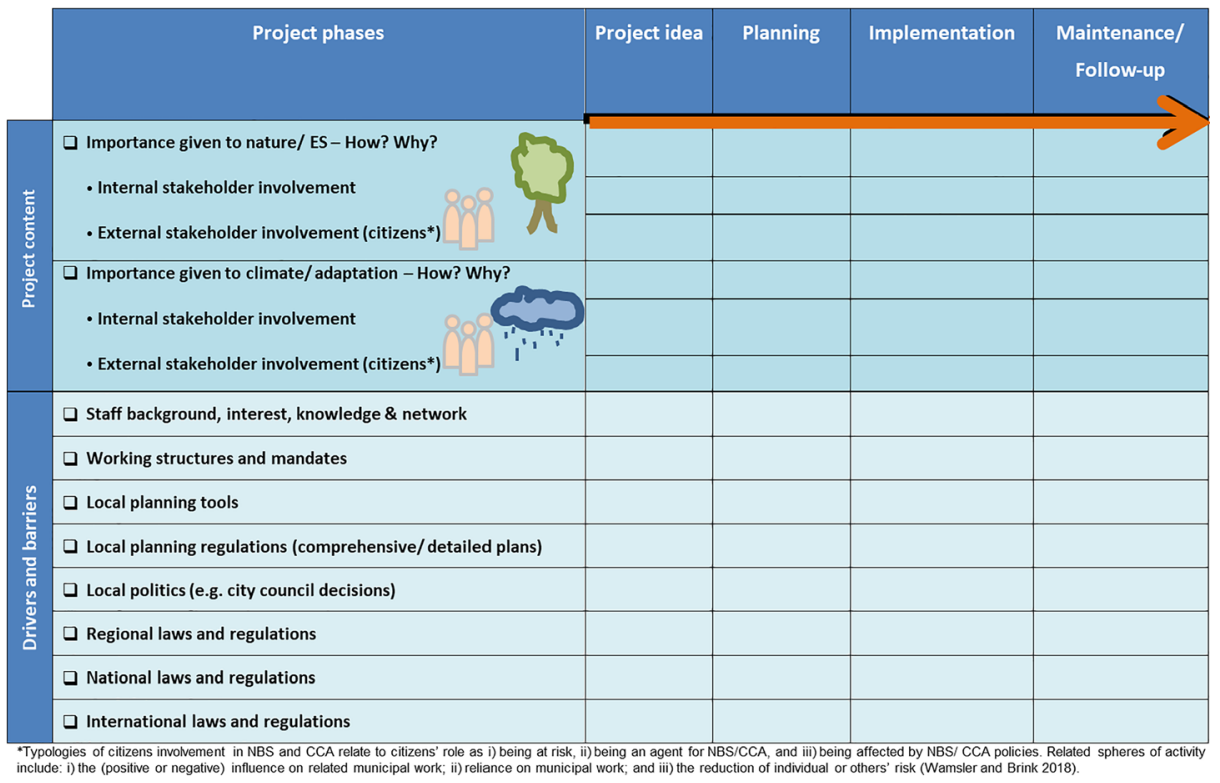

Framework for mainstreaming (nature-based approaches to) climate change adaptation

Levels/dimensions $^{\mathrm{a}} \quad$ Mainstreaming strategies

$\begin{array}{ll}\text { Horizontal } & \text { (1) Add-on } \\ \text { mainstreaming } & \text { mainstreaming }\end{array}$

(2) Programmatic mainstreaming

(3) Inter- and intra-organizational mainstreaming

$\begin{array}{ll}\text { Vertical } & \text { (4) Managerial } \\ \text { mainstreaming } & \text { mainstreaming }\end{array}$

(5) Regulatory mainstreaming

(6) Directed mainstreaming
The establishment of specific on-the-ground projects or programs that are not an integral part of the department's core objectives but directly target adaptation $^{\mathrm{a}}$ or related aspects.

The modification of department's core work by integrating aspects related to adaptation ${ }^{\mathrm{a}}$ into on-the-ground projects or programs.

Promotes collaboration between individual sections or departments and other stakeholders (departments, committees, organizations, or governmental bodies) in order to generate shared knowledge, develop competence, and take actions to advance adaptation ${ }^{\text {a }}$.

The modification of managerial and working structures, including internal formal and informal norms and job descriptions as well as the configuration of sections or departments to better address and institutionalize aspects related to adaptation ${ }^{\text {a }}$.

The modification of planning procedures and related activities by formal and informal plans, policies, regulations, and legislations that lead to the integration of adaptation $^{\mathrm{a}}$.

Supports or redirects the focus onto aspects related to integrating adaptation ${ }^{\text {a }}$ by providing topic-specific funding, promoting new projects, supporting the education of staff, or directing responsibilities.

\footnotetext{
a The mainstreaming framework can be applied to overall adaptation, or specific aspects of it (e.g., nature-based approaches), as well as to other cross-cutting topics such as climate change mitigation. Source: adapted from Wamsler and Pauleit (2016)
} 
Open Access This article is distributed under the terms of the Creative Commons Attribution 4.0 International License (http://creativecommons.org/licenses/by/4.0/), which permits unrestricted use, distribution, and reproduction in any medium, provided you give appropriate credit to the original author(s) and the source, provide a link to the Creative Commons license, and indicate if changes were made.

\section{References}

Abson DJ, Fischer J, Leventon J, Newig J, Schomerus T, Vilsmaier U, von Wehrden H, Abernethy P, Ives CD, Jager NW, Lang DJ (2017) Leverage points for sustainability transformation. Ambio 46:30-39

Adger N, Arnell N, Tompkins E (2005) Successful adaptation to climate change across scales. Glob Environ Chang 15:77-86

Adger WN, Quinn T, Lorenzoni I, Murphy C, Sweeney J (2013) Changing social contracts in climate-change adaptation. Nat Clim Chang 3:330-333

Andersson E (2006) Urban landscapes and sustainable cities. Ecol Soc 11(1):34

Bateson G (1979) Mind and nature: a necessary unity-advances in systems theory, complexity, and the human sciences. Hampton Press, New Jersey, USA

Beierle TC, Konisky DM (2000) Values, conflict, and trust in participatory environmental planning. J Policy Anal Manag 19(4):587e602

Bjärstig T, Thellbro C, Stjernström O, Svensson J, Sandström C, Sandström P, Zachrisson A (2018) Between protocol and reality-Swedish municipal comprehensive planning. Eur Plan Stud 26(1):35-54

Blennow K, Persson J, Wallin A, Vareman N, Persson E (2014) Understanding risk in forest ecosystem services: implications for effective risk management, communication and planning. Forestry cpt032

Brink E (2018) Adapting cities: ecosystem-based approaches and citizen engagement in municipal climate adaptation in Scania, $\mathrm{PhD}$ dissertation, Lund University Centre for Sustainability Studies, Sweden

Brink E, Wamsler C (2018) Collaborative governance for climate change adaptation: mapping citizenmunicipality interactions. Environ Policy Gov 28(2):82-97

Brink E, Wamsler C (2019) Citizen engagement in climate adaptation surveyed: the role of values, worldviews, gender and place. J Clean Prod 209:1342-1353

Bristow J (2019) Mindfulness in politics and public policy. Curr Opin Psychol 28:87-91

Buijs A, Mattijssen T, van der Jagt A, Ambrose-Oji B, Andersson E, Elands B, Steen Møller M (2017) Active citizenship for urban green infrastructure: fostering the diversity and dynamics of citizen contributions through mosaic governance. Curr Opin Environ Sustain 22:1-6

Bulkeley H, Mol AP (2003) Participation and environmental governance: consensus, ambivalence and debate. Environ Values 12(2):143-154

Burns D (2007) Systemic action research: a strategy for whole system change. Policy Press

Burton P, Mustelin J (2013) Planning for climate change: is greater public participation the key to success? Urban Policy Res 31(4):399-415

Checker M (2011) Wiped out by the "Greenwave": environmental gentrification and the paradoxical politics of urban sustainability. City Soc 23:210-229

Clausen LT (2016) No interest in landscape? The art of non-participation in Danish landscape planning. Landsc Res 42(4):412-423

Cooke B, Kothari U (Eds.) (2001) Participation: the new tyranny? Zed books

Davoudi S, Crawford J, Mehmood A (Eds.) (2010) Planning for climate change: strategies for mitigation and adaptation for spatial planners. Earthscan

DC (2014) Global Green Economy Index (4th Ed). Dual Citizen LLC. https://dualcitizeninc.com/GGEIReport2014.pdf

EC (2015) Towards an EU research and innovation policy agenda for nature-based solutions \& re-naturing cities. Final report of the Horizon 2020 expert group on 'nature-based solutions and re-naturing cities' directorategeneral for research and innovation. Eurpoean Commission. Eurpoean Union, Luxembourg

Eggermont H, Balian E, Azevedo JMN, Beumer V, Brodin T, Claudet J, Fady B, Grube M, Keune H, Lamarque P, Reuter K, Smith M, van Ham C, Weisser WW, Le Roux X (2015) Nature-based solutions: new influence for environmental management and research in Europe. Gaia-Ecological Perspectives for. Sci Soc 24:243-248

Few R, Brown K, Tompkins EL (2007) Public participation and climate change adaptation: avoiding the illusion of inclusion. Clim Pol 7:46-59

Folke C, Hahn T, Olsson P, Norberg J (2005) Adaptive governance of social-ecological systems. Annu Rev Environ Resour 30(1):441e473

Glicken J (2000) Getting stakeholder participation "right": a discussion of participatory processes and possible pitfalls. Environ Sci Policy 3(6):305-310

Glaas E, Neset T-S, Kjellström E, Almås A-J (2015) Increasing house owners adaptive capacity: compliance between climate change risks and adaptation guidelines in Scandinavia. Urban Clim 14(1):41-51 
Glaser B, Strauss A (1967) The discovery of grounded theory: strategies for qualitative research. Aldine de Gruyter, New York

Glassman M, Erdem G (2014) Participatory action research and its meanings: Vivencia, praxis, conscientization. Adult Educ Quart 64(3):206-221

Greenwood DJ, Levin M (2006) Introduction to action research: social research for social change. SAGEPublications, Thousand Oaks

Hardin R (2013) Government without trust. J Trust Res 3(1):32-52

Hassenforder E, Smajgl A, Ward J (2015) Towards understanding participatory processes: framework, application and results. J Environ Manage 157:84-95

Hegger DL, Mees HL, Driessen PP, Runhaar HA (2017) The roles of residents in climate adaptation: a systematic review in the case of the Netherlands. Environ Policy Gov 27(4):336-350

Hertin J, Berkhout F (2001) Ecological modernisation and EU environmental policy integration. University of Sussex, SPRU

Huq N, Renaud F, Sebesvari Z (2013) Ecosystem based adaptation (EBA) to climate change — integrating actions to sustainable adaptation. In Impacts World 2013: International Conference on Climate Change Effects (pp. 151-164). Potsdam: Potsdam Institute for Climate Impact Research

IPCC. (2014) Climate change 2014: impacts, adaptation, and vulnerability. C. B. Field, V. R. Barros, D. J. Dokken, K. J. Mach, M. D. Mastrandrea, T. E. Bilir, M. Chatterjee, K. L. Ebi, Y. O. Estrada, R. C. Genova, B. Girma, E. S. Kissel, A. N. Levy, S. Maccracken, P. R. Mastrandrea, and L. L. White, editors. Working Group II contribution to the Fifth Assessment Report of the Intergovernmental Panel on Climate Change (IPCC). Cambridge University Press, Cambridge, UK

IPCC (2018) Strengthening and implementing the global response [Coninck, H. de., Revi, A., Babiker, M., Bertoldi, P., Buckeridge, M., Cartwright, A., Dong. W., Ford, J., Fuss, S., Hourcade, J.C., Ley, D., Mechler, R., Newman, P., Revokatova, A., Schultz, S., Steg, L. \& Sugiyama, T.], chapter 4 in: Global warming of $1.5^{\circ}$ C. An IPCC Special Report on the impacts of global warming of $1.5^{\circ} \mathrm{C}$ above pre-industrial levels and related global greenhouse gas emission pathways, in the context of strengthening the global response to the threat of climate change, sustainable development, and efforts to eradicate poverty [V. Masson-Delmotte, P. Zhai, H. O. Pörtner, D. Roberts, J. Skea, P.R. Shukla, A. Pirani, W. Moufouma-Okia, C. Péan, R. Pidcock, S. Connors, J. B. R. Matthews, Y. Chen, X. Zhou, M. I. Gomis, E. Lonnoy, T. Maycock, M. Tignor, T. Waterfield (eds.)]. Cambridge University Press, Cambridge, UK

Irvin RA, Stansbury J (2004) Citizen participation in decision making: is it worth the effort? Public Adm Rev 64(1):55-65

IUCN (2008) Ecosystem-based adaptation: an approach for building resilience and reducing risk for local communities and ecosystems. A submission by IUCN to the Chair of the AWG- LCA with respect to the Shared Vision and Enhanced Action on Adaptation. UNFCCC

Jones R (2008) People/states/territories: the political geographies of British state transformation. Blackwell, Oxford

Jordan A, Lenschow A (2000) Greening the European Union: what can be learned from the 'leaders' of EU environmental policy? Eur Environ 10(3):109-120

Kabisch N, Frantzeskaki N, Pauleit S, Naumann S, Davis M, Artmann M, Haase D, Knapp S, Korn H, Stadler J, Zaunberger K, Bonn A (2016) Nature-based solutions to climate change mitigation and adaptation in urban areas: perspectives on indicators, knowledge gaps, barriers, and opportunities for action. Ecol Soc 21(2):39

LabGov.City (2019) The co-cities report: building a "co-cities index" to measure the implementation of the EU and UN Urban Agenda. Available at: http://labgov.city/wp-content/uploads/sites/19/Co-cities-Open-Book-Report.pdf

Lankao PR (2008) Urban areas and climate change: review of current issues and trends issues paper for the 2011 global report on human settlements. National centre for Atmospheric Research. Boulder, USA

Lewis JG, Weigert A (1985) Trust as a social reality. Social Force 36:967-985

län L i S (2014) Biologisk mångfald I. De Skånska Kommunernas Planeringsunderlag Och Verksamheter Malmö, Länsstyrelsen i Skåne län, Sweden

Länsstyrelserna (2012) Klimatanpassning I. Fysisk Planering_Vägledning Från länsstyrelserna Länsstyrelserna, Malmö Sweden

Lemos MC, Agrawal A (2006) Environmental governance. Annu Rev Environ Resour 31:297-325

Lilley R, Whitehead M, Howell R, Jones R, Pykett J (2014) Mindfulness, behaviour change, and engagement in public policy: an evaluation. Copy available from Rachel Lilley, Aberystwyth University

MacKinnon K, Sobrevila C, Hickey V (2008) Biodiversity, climate change and adaptation; nature-based solutions from the World Bank portfolio. The International Bank for Reconstruction and Development, The World Bank, Washington

Maes J, Jacobs S (2015) Nature-based solutions for Europe's sustainable development. Conserv Lett 10(1):121-124

Mair D., Smillie L., La Placa G., Schwendinger F., Raykovska M., Pasztor Z., van Bavel R (2019) Understanding our political nature: how to put knowledge and reason at the heart of political decision-making, Science for Policy report by the Joint Research Centre (JRC), the European Commission's science and knowledge service. EUR 29783 EN, Publications Office of the European Union, Luxembourg 
Mattijssen T, Buijs A, Elands B, Arts B (2018) The 'green' and 'self' in green self-governance-a study of 264 green space initiatives by citizens. J Environ Policy Plan 20(1):96-113

Measham TG, Preston BL, Smith TF, Brooke C, Gorddard R, Withycombe G, Morrison C (2011) Adapting to climate change through local municipal planning: barriers and challenges. Mitig Adapt Strateg Glob Chang 16(8):889-909

Mees HL, Driessen PP, Runhaar HA (2015) "Cool" governance of a "hot" climate issue: public and private responsibilities for the protection of vulnerable citizens against extreme heat. Reg Environ Chang 15(6):1065-1079

Mees H, Crabbé A, Driessen PP (2017) Conditions for citizen co-production in a resilient, efficient and legitimate flood risk governance arrangement. A tentative framework. J Environ Policy Plan 19(6):827-842

Mees H, Crabbé A, Alexander M, Kaufmann M, Bruzzone S, Lévy L, Lewandowski J (2016) Coproducing flood risk management through citizen involvement: insights from cross-country comparison in Europe

Mees, H., Uittenbroek, C.J., Hegger, D. \& Driessen, P. (2019) From citizen participation to government participation: an exploration of the roles of local governments in community initiatives for climate change adaptation in the Netherlands. Environmental policy and governance. Environmental Policy and Governance 29(3):198-208

Ministry of the Environment (2013) Making the value of ecosystem services visible: proposals to enhance wellbeing through biodiversity and ecosystem services. Stockholm, Sweden

Nesshöver C, Assmuth T, Irvine KN, Rusch GM, Waylen KA, Delbaere B, Haase D, Jones-Walters L, Keune H, Kovacs K, Külvik M, Rey F, van Dijk J, Vistad OI, Wilkinson ME, Wittmer H (2017) The science, policy and practice of nature-based solutions: an interdisciplinary perspective. Sci Total Environ 579:1215-1227

Nightingale AJ (2015) Commons and alternative rationalities: subjectivity, emotion and the (non)rational commons, Bollier, D., Helfrich, S. (Eds.), Patterns of Commoning, The Commons Strategy Group, Off the Common Press

Nightingale AJ (2017) Power and politics in climate change adaptation efforts: struggles over authority and recognition in the context of political instability. Geoforum 84:11-20

O'Brien K (2018) Is the $1.5 \mathrm{C}$ target possible? Exploring the three spheres of transformation. Curr Opin Environ Sustain 31:153-160

O'Brien K, Sygna L (2013) Responding to climate change: the three spheres of transformation. Proceedings of transformation in a changing climate, 19-21 June. University of Oslo, Oslo, Norway, p 2013

O'Brien K, Hayward B, Berkes F (2009) Rethinking social contracts: building resilience in a changing climate. Ecol Soc 14(2):12

OECD (2010) Better regulation in Europe: Sweden. Transparency through consultation and communication, chapter 3. Available at: https://www.oecd.org/gov/regulatory-policy/45418324.pdf

O'Faircheallaigh C (2010) Public participation and environmental impact assessment: purposes, implications, and lessons for public policy making. Environ Impact Assess Rev 30(1):19-27

Parodi O, Tamm K (Eds.) (2018) Personal sustainability: exploring the far side of sustainable development. Routledge

Pauleit S, Liu L, Ahern J, Kazmierczak A (2011) Multifunctional green infrastructure planning to promote ecological services in the city, Chapter 5.3, Niemelä, J., Breuste, J., Elmqvist, T., Guntenspergen, G., James, P., McIntyre, N. (Eds) Urban ecology: patterns, processes, and applications, Oxford Scholarship

Purcell M (2006) Urban democracy and the local trap. Urban Stud 43(11):1921-1941

Purcell M, Brown JC (2005) Against the local trap: scale and the study of environment and development. Prog Dev Stud 5(4):279-297

Rauken T, Mydske PK, Winsvold M (2014) Mainstreaming climate change adaptation at the local level. Local Environ 20(4):408-423

Renn O, Schweizer PJ (2009) Inclusive risk governance: concepts and application to environmental policy making. Environ Policy Gov 19(3):174-185

Roberts D, Boon R, Diederichs N, Douwes E, Govender N, Mcinnes A, Mclean C, O’Donoghue S, Spires M (2012) Exloring ecosystem-based adaptation in Durban, South Africa: "learning-by-doing" at the local government coal face. Environ Urban 24:167-195

Rowe G, Frewer LJ (2004) Evaluating public-participation exercises: a research agenda. Sci Technol Hum Values 29(4):512-556

Runhaar H, Wilk B, Persson Å, Uittenbroek C, Wamsler C (2018) Mainstreaming climate adaptation: taking stock about "what works" from empirical research worldwide. Reg Environ Chang 18(4):1201-1210

Sarzynski A (2015) Public participation, civic capacity, and climate change adaptation in cities. Urban Clim 14: $52-67$

SFS (2010:900) Plan- och bygglag (2010:900). Svensk författningssamling (SFS)

Shogren JF, Taylor LO (2008) On behavioral-environmental economics. Rev Environ Econ Policy 2(1):26-44

SMHI (Sveriges Meteorologiska och Hydrologiska Institut) (2011) Klimatanalys för Skåne län. Norrköping, Sweden 
SOU (2013) Making the value of ecosystem services visible. Proposals to enhance well-being through biodiversity and ecosystem services. Swedish Government Enquiries, SOU 2013:68, Stockholm

SOU (2007) Sverige inför klimatförändringarna-hot och möjligheter. SOU 2007:60

Sutherland R (2018) Policy making under uncertainty. Behav Publ Policy 2:246-251

Tippett J, Handley JF, Ravetz J (2007) Meeting the challenges of sustainable development e a conceptual appraisal of a new methodology for participatory ecological planning. Prog Plan 67(1):9-98

van Ham C, Klimmek H (2017) Partnerships for nature-based solutions in urban areas-showcasing successful examples, 275-289 Kabisch, N., Korn, H., Stadler, J., Bonn, A (Eds) Nature-based solutions to climate change adaptation in urban areas, Springer

van der Jagt A, Elands B, Ambrose-Oji B, Gerházi E, Møller M, Buizer M (2016) Participatory governance of urban green spaces: trends and practices in the EU. Nordic J Architect Res 3:11-39

Wamsler C, Brink E (2014a) Planning for climatic extremes and variability: a review of Swedish municipalities' adaptation responses. Sustainability 6:1359-1385

Wamsler C, Brink E (2014b) Interfacing citizens' and institutions' practice and responsibilities for climate change adaptation. Urban Clim 7:64-91

Wamsler C, Raggers S (2018) Principles for supporting city-citizen commoning for climate adaptation: from adaptation governance to sustainable transformation. Environ Sci Policy 85:81-89

Wamsler C (2014) Cities, disaster risk and adaptation. Routledge, London

Wamsler C (2016) From risk governance to city-citizen collaboration: capitalizing on individual adaptation to climate change. Environ Policy Gov 26(3):184-204

Wamsler C (2017) Stakeholder involvement in strategic adaptation planning: Transdisciplinarity and coproduction at stake? Environ Sci Pol 75:148-157

Wamsler C (2018a) Contemplative sustainable futures: the role of individual inner dimensions and transformation in sustainability research and education, Chapter in: Handbook of Sustainability and Humanities, Leal, W, Consorte McCrea, A (eds). World Sustainability Series of Springer

Wamsler C (2018b) Mind the gap: the role of mindfulness in adapting to increasing risk and climate change. Sustain Sci 13:1121-1135

Wamsler C, Pauleit S (2016) Making headway in climate policy mainstreaming and ecosystem-based adaptation: two pioneering countries, different pathways, one goal. Clim Chang 137(1-2):71-87

Waylen KA, Blackstock KL, Marshall KB, Dunglinson J (2015) Participation-prescription tension in natural resource management: the case of diffuse pollution in Scottish water management. Environ Policy Gov 25(2):111-124

Weber M (1991) From Max Weber: essays in sociology, edited with an introduction by HH Gerth and CW Mills. Routledge, London

Wilkinson C, Saarne T, Peterson G, Colding J (2013) Strategic spatial planning and the ecosystem services concept-an historical exploration. Ecol Soc 18(1):37

World Bank (2015) World Development Report 2015: mind, society and behavior. World Bank Group, Washington

Publisher's note Springer Nature remains neutral with regard to jurisdictional claims in published maps and institutional affiliations.

\section{Affiliations}

\section{Wamsler ${ }^{1} \cdot$ J. Alkan-Olsson ${ }^{2} \cdot$ H. Björn ${ }^{3} \cdot$ H. Falck ${ }^{4} \cdot$ H. Hanson ${ }^{2} \cdot$ T. Oskarsson ${ }^{5}$ • E. Simonsson $^{6}$ • F. Zelmerlow ${ }^{7}$}

1 Lund University Centre for Sustainability Studies (LUCSUS), Lund, Sweden

2 Lund University Centre for Environmental and Climate Research (CEC), Lund, Sweden

3 Lomma Municipality, Sweden

4 Malmö Municipality, Sweden

5 Eslöv Municipality, Sweden

6 Kristianstad Municipality, Sweden

7 Höganäs Municipality, Sweden 